\title{
Cumhuriyet Dönemi (1929-1961) Gördes'in Geleneksel Süislemeli Mezar Taşlarından Bazı Örnekler
}

\author{
H. KAMIL BIĊicí \\ Dr., GAZI Ü. FEN-EDEBIYAT FAKÜLTESI
}

\begin{abstract}
The compositions on the gravestones with the Turkish alphabet which we have studied are on the pediments and footstones. Acaunthus, cypress and different kinds of flowers were shown within a unique form to show a wholeness. So, different motifs were portrayed together to fullfill the stone. The samples with floral, objective and geometric depictions which were made after the rebuclic are from between 1929 and 1961 and covers a 32 years time. It's attracted the attention both, the clear workman-ships and harmonius compositions on the stones. Also, some gravestones show a simpleness and linear-decorations. The gravestones with floral decorations are culiar to Gordes tradition.
\end{abstract}

key words

Gravestones: Tradition, Decoration, Floral, Objective.

Gördes Ege Bölgesinde Manisa iline bağlı bir ilçedir. Topraklarını doğuda aynı ilin Demirci, güneyde Kula ve Salihli, batıda Akhisar, kuzeyde ise Balıkesir'in Sındırgı ilçeleri çevirir. İlçe, Uşak-Gördes yaylasının batı ucundadır. Batı Anadolu'da Gediz Irmağı'na kavuşan Kum Çayı'nın yukarı kısmında Gördes Deresi ve bu derenin batı kıyısındaki yamaç üzerinde yer alan 450500 rakımlı bir kasabadır. Bu bölgede geçmişte yer yer toprak kaymaları olduğundan, ${ }^{1} 1940$ yllında kasaba $3 \mathrm{~km}$. ilerideki kayalık bir zemin üzerine yeniden inşa edilmiştir.

S. Sami İlker, Tuncay, Halil Aker (Anlatan: Zekeriya Yurdoğlu), Bir Zamanlar Gördes, Manisa 1999, s. 266-274. 
Milli kültürümüz bakımından Ege Bölgesine has özellikler taşıyan ancak ülkemizde halıları dışında pek tanınmayan Gördes ilçesi'nin kültürel dokusunda en önemli unsurlardan biri, eski Gördes'te bulunan Ağalar Mezarlığı, Büyük Mezarlık, Garipler Mezarlığı, Hüseyni Baba Mezarlığındaki mezar taşlarıdır $^{2}$. Bu taşlardaki sanatsal zenginlik eski zengin mazisine sessizce şahitlik eder gibidir. Cumhuriyet döneminin Latin alfabeli geleneksel ve Osmanlı dönemine ait mezar taşlarının bulunduğu mezarlıklarda yer alan yeni tarihli şahideler geçmişteki kimi örnekleri hatırlattığ için önem taş1maktadır. Bu mezar taşları geçmişin taş işçiliğinin estetik beğenisi yanında, Gördes'teki yerleşik hayat ve kültürel doku konusunda da bizleri aydınlatmaktadır. Burada önemli olan husus, bezemeli mezar taşlarında gözlenen; taşın ön veya arka yüzünün bir kısmının, ya da bütün yüzeyinin süslemelerle işlenmiş olmasıdır. Süslemeler genellikle tepeliklerde yoğunlaşmakta ve ayrıca ayak taşlarında da yer almaktadır.

Cumhuriyetin ilanından itibaren Gördes mezarlıklarında, geleneksel Osmanlı üslubunu çağrıştıran 30 kadar yakın tarihli mezar taşı bulunmaktadır. Bu mezar taşlarından 10 tanesi mimari bezeme özelliklidir. Çoğunluğu cami tasvirli olan bu grubu başka bir makalede ${ }^{3}$ değerlendirdiğimiz için bu makalemize onu dahil etmedik. Mezarlıklarda Osmanlı dönemini hatırlatan, bitkisel, geometrik ve nesnel bezeme özellikli yirmiye yakın mezar taşı içerisinden daha iyi durumda olan, 14 tanesini çalışma konumuza dahil ettik. Bu çalışmada incelediğimiz mezar taşlarıyla birlikte, Osmanlı mezar taşlarından bazılarının fotoğraflarını da aralarındaki yakın benzerliği, etkileşimi göstermesi açısından yer vermeye çalıştık. Yakın tarihli mezar taşlarıyla, Osmanlı mezar taşları içerisinden süsleme yönünden benzer olanların bir kısmının da birbirlerine yakın durumda bulundukları gözlenmiştir. Dolayısıyla ele aldığımız mezar taşları, mezar sahiplerinin mezarlık çevresinde gördüğü Osmanlı taşlarından etkilenerek sipariş vermiş ve yaptırmış olabilecekleri yönündedir. Bezemeleri Osmanlı üslubunu andırır şekilde yapılan az sayıdaki Latin alfabeli mezar taşı, geçmişin izlerini aksettirmesi açısından önem kazandığı için bu çalışmada değerlendirilmiştir. Makale konumuz Gördes'teki Osmanlı Dönemi Mezar Taşları olmadığı gibi tezle ilgili genel kısa özelliklerin, bazı alıntıların dışında tezden bir bölüm değildir.

2 Bkz. H.Kamil Biçici, Manisa Gördes’te Bulunan Osmanlı Dönemi Süslemeli Mezar Taşları, Gazi Ünv. Sosyal Bilimler Enstitüsü (Basılmamış Doktora Tezi), Sanat Tarihi Anabilim Dalı, Ankara, 2004.

3 Bu konuyla ilgili geniş bilgi için bkz., H.Kamil Biçici, "Gördes’te Bulunan Mimari Bezemeli Mezar Taşı İşçiliğinden Bazı Örnekler”, Manas Ünv. Sos. Bil. Der. Yayın no: 66, Süreli Yay. Dizisi: 18, S. 13, Bişkek, s. 1-15, 2005: 1-15. 
Buradaki amaç eski ile yeniyi karşılaştırıp, değerlendirmek, eskinin daha çok devamı niteliğinde olan yeni örnekleri tanıtarak bir fikir vermektir.

2004-2005 yılları içerisindeki tez sonrası çalışmasına dayanan, inceleyeceğimiz 1929-1961 yıllarına ait örnekler, 2001-2004 yılları içerisinde tez kapsamında Gördes mezarlıklarında yapmış olduğumuz Osmanlı dönemine ait örneklerin bir devamı gibidir. Osmanlı devleti yıkılıp, Cumhuriyet kurulunca yörenin insanları geçmişlerini unutmamışlar, atalarına, yakınlarına ait taşları korumaya gayret etmelerinin yanında, az örnekle de olsa geçmişin izlerini mezar taşlarında yansıtmaya, yaşatmaya çalışmışlardır.

Osmanlı sonrası mezar taşlarını tanıtmadan önce makale konumuza süsleme ve kompozisyonda kullanılan motifler yönünden dayanak olan, Gördes'teki Osmanlı dönemine ait süslemeli mezar taşlarından bahsetmek gerekir:

Gördes'te Ağalar, Büyük, Garipler, Hüseyni Baba Mezarlıklarından üçyüzotuzsekiz mezar taşı, Belediye'ye ait Soğuk Hava Deposu önünde bulunan mezar taşlarından beş mezar taşı incelenerek, ilgili tez çalışmamızda yer almıştır. Mezar taşlarında tarihi bilinen bütün örnekler XVIII.yy.başı ile XX.yy. ilk çeyreği arasındadır. Üçyüzkırküç örnekten yetmişsekiz tanesi XVIII.yy., yüzdoksanbeş tanesi XIX.yy., otuziki tanesi XX.yy. ilk çeyreği, kırk tanesinin de tarihi bilinmemekle birlikte benzer malzeme, form ve bezeme özelliklerine göre tarihlendirilip, XVIII-XIX.yy. arasındaki bir zaman diliminde olabileceği düşünülmektedir. Mezar taşlarının yedi tanesi taş, geri kalanı da mermer malzemeden yapılmıştır. Mezar taşlarının büyükten küçüğe doğru yükseklikleri $190 \mathrm{~cm}$. ile $31 \mathrm{~cm}$., genişlikleri $54 \mathrm{~cm}$. ile $15 \mathrm{~cm}$., kalınlıkları ise 38 ile $3 \mathrm{~cm}$. arasında değişmektedir. Gördes'te bulunan Osmanlı dönemi mezar taşları şahideli tiptedir. Örneklerin çoğu dikdörtgen gövdeli, bir kıs$\mathrm{m}$ da dikdörtgen prizmal gövdelidir. Ellidört mezar taşında ayak taşı bulunmaktadır. Seksenyedi mezar taşında ikisi kadın başlığı olmak üzere kavuk, sarık, fes, külah türü başlık yer almaktadır. Şahidelerin yapım tekniği olarak oyma ve kazıma karşımıza çıkmaktadır. Süsleme tekniği olarak oyma, kazıma ve boyama tekniği uygulanmıştır.Kazıma tekniği daha çok ayak taşlarında göze çarpmaktadır. Taşın üzerine çizilerek yapılan süsleme oldukça şematik ve yüzeyseldir. Boyama tekniğinde, doğal boyalarla daha çok taşın kitabesi renklendirilmiştir. Az örnekte de tepelikteki süslemenin üzeri boyanmıştır. Kitabelerin ve süslemelerin çoğu kabartma görünümündedir.

Süsleme konusu olarak bitkisel, nesneli, geometrik bezeme unsurları ve yazı kullanılmıştır. Bitkisel tasvirlerde en çok akantus, servi, gül, lale, kır çiçekleri, bazen tek, bazen çiçek demetleri şeklinde, bazen de mimari ve geometrik unsurlarla beraber kullanılmıştır. Nesneli bezemelerde; değişik 
tipte vazolar, saksı, meyve kaseleri ve içinde yer alan meyveler, çiçekler, inci ve gerdanlık dizisi, geometrik süslemelerde; çarkıfelek, burma, ışın çubuğu, hilal, saç örgüsü, zikzak, testere dişi, yıldız, yürek motifi diğer örneklerde olduğu gibi taşın tepeliğinde, alınlığında, alınlıkla kitabeyi çeviren yatay kuşak veya kitabeyi ters U şeklinde saran kuşak içerisinde, kitabenin üst yan köşelerinde ve ayak taşlarında karşımıza çıkmaktadır. Genellikle tabiattan alınan bitkisel süslemeler çoğunlukla natüralist bir yaklaşımla taşın yüzeyine işlenmiştir. Mimari kompozisyonlar taşın alınlık kısmında yer almaktadır. Bu kompozisyonlar akantus, serviler, çiçekler, vazo, meyve kasesi ve diğer bitkisel unsurlarla birlikte tasvir edilmiştir. Cami, türbe ve evlerin yer aldığı mimari tasvirler yüzbir mezar taşında göze çarpmaktadır. On mezar taşında sadece alem ve cami kubbesinin küçük bir kısmı verilerek caminin bir ünitesiyle cami vurgulanmak istenmiştir. Gördes'te Osmanlı sonrası aynı anlayışla yapılan mimari bezemeli benzer mezar taşları da bulunmaktadır. ${ }^{4}$ Mimari bezeme mezar taşlarının dışında halılarda, mimari süslemelerde, çeşmelerde, şadırvanlarda, duvar resimlerinde, madeni eserlerde, çinilerde, seramiklerde, minyatürde, işlemelerde, kuşevlerinde özellikle Batılılaşmanın etkisini yoğun olarak gösterdiği XVIII ile XIX. yy.da ortak beğeniler sonucu ortaya çıktığı görülmüsstür. Bu benzer anlayışın cumhuriyetin ilanından sonra da devam ettiği gözlenmektedir ${ }^{5}$. Osmanlı döneminde mimari bezemeli Osmanlı mezar taşları kadınlara ait mezarlarda ortaya çıkarken, ilk defa bu tür mimari bezemeler yedi erkek mezarında da karşımıza çıkmaktadır. Bu da bizlere eski geleneklerin değişerek,az da olsa devam ettiğini göstermesi açısından önem taşımaktadır ${ }^{6}$. Ayrıca burada değinmediğimiz, Osmanlı mezar taşlarındaki yazılı bezemeler ile kitabelerde yer alan yazılara göre Gördes'teki sosyal ve dini yaşama ait bilgiler (yöreye ait kadın erkek isimleri, yer ve mahalle adları, bulaşıcı hastalıktan ölen olup olmadığ1, şair,hattat ve diğer meslek isimleri, dini ünvanlar, bürokrat ve üst rütbeli askerler, mezar taşı kitabelerinde yer alan başlıklar) tez çalışmasıyla ilgili diğer bir makalede işlenmiştir. ${ }^{7}$ Bunun yanında yakın tarihli mezar taşlarında 7 mezar taşında doğum ve ölümle ilgili bilgilerin yanında (17 ile 77 yaş grubu arasında), Osmanlı dönemi soy ve lakap isimlerinden olan Nasuhoğlu (No:2,6,12), Ustaoğlu (No:11) adları dikkat çekmektedir.

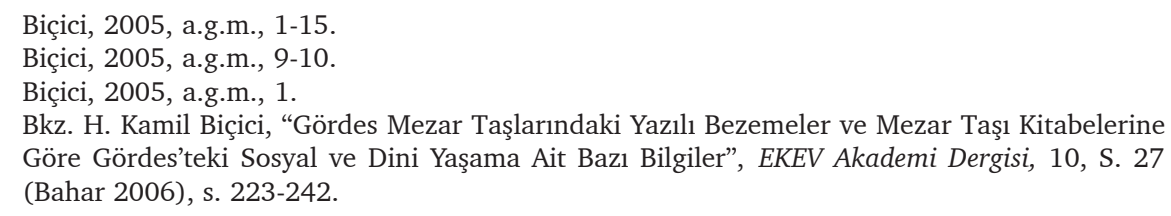


Yukarıda değinmeye çalıştığımız Osmanlı dönemi mezar taşları ile incelediğimiz Türkçe Latin alfabeli, bezemeli mezar taşları arasında büyük benzerlik olduğu görülmektedir. Bu benzerlik kompozisyonlarda süslemenin ya kısmen ya da tamamen ele alınmış biçiminde karşımıza çıkmaktadır. Kompozisyon içinde bitkisel ağırlığın göze çarptığı görülmüş, akantus, servi ve çiçeklerin çeşitli unsurlarla birlikte konuya bütünlük katmak amacıyla işlendiği gözlenmiştir. Cumhuriyetin ilanından sonra yapılan bitkisel, nesneli ve geometrik tasvirli örnekler 1929 ile 1961 tarihleri arasındaki 32 yıllık bir zaman dilimini kapsamaktadır. No:1'deki mezar taşı (Fotoğraf No:12, çizim:1) Osmanlı dönemine ait bir mezardır. Fakat bu mezar taşının Osmanlıca kitabesi Cumhuriyetin ilanından sonra silinip, yeni Türkçe kullanımı olması sebebiyle, 1916 tarihli bu mezar taşı da incelemeye dahil edilmiştir.

\section{Mezar Taşı No 1}

Fotoğraf No: $1-2$, çizim:1

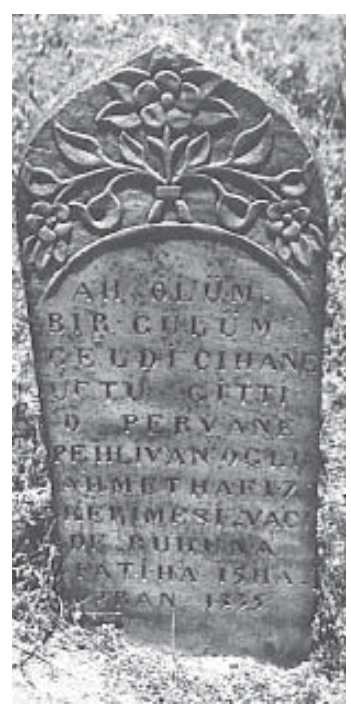

Fotoğraf 1. Vacide, baştaşı, 1916 Büyük Mezarlık

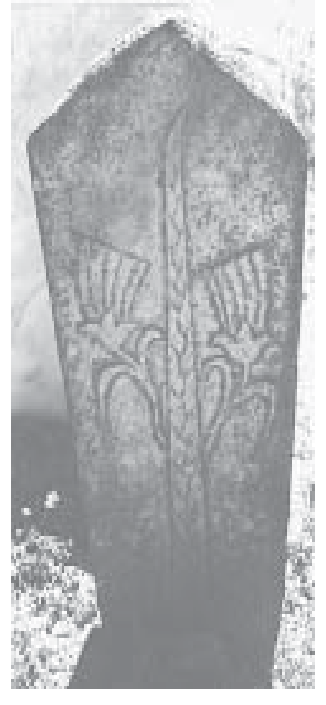

Fotoğraf 2. Vacide, ayaktaşı, 1916, Büyük Mezarlık

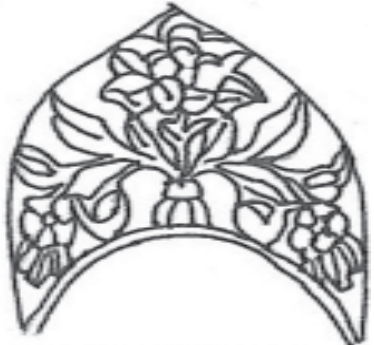

No.1, çizim 1, Vacide, baştaş1,1916 Büyük Mezarlık

Tarih: H.1335/M.1916,

Yeni Türk alfabesinin kabulünden sonra tekrar elden geçtiğinden dolayı ikinci tarihlendirme 1929 ile 1935 arası olabilir.

Yeri: Büyük Mezarlık 
Üslup: Antinatüralist verilmiştir.

Kime Ait Olduğu: Ahmet Hafız Kerimesi Vacide

Kitabesi: -Ah ölüm, -Bir gülüm, -Geldi cihan, -Uçtu gitti, -O pervane, Pehlivan oğlu, -

Ahmet Hafiz, -Kerimesi Vaci, -de ruhuna, -Fatiha 15 Haziran 1335.

Biçimi: Dikdörtgen gövde formludur.

Bugünkü Durumu: Sağlam durumdadır.

Türü: Kadın mezarıdır.

Malzeme: Mermer malzeme kullanılmıştır.

Ölçü: Baştaşı Boy: $82 \mathrm{~cm}$. En: $33 \mathrm{~cm}$. Kal.: $6 \mathrm{~cm}$. Ayaktaş1: Boy:72 cm. En:29 cm. Kal.:6 cm.

Konu: Bitkisel (yaprak, rozet, servi, horoz ibiği) ve nesneli (çiçek bağı) işlenmiştir.

\section{Tanım ve Kompozisyon}

Alt kısımdan üst kısma doğru her iki yönden, genişleyerek devam eden mezar taşının, gövde ile sivri tepelik kısmını yuvarlak kemer biçimli bir bordür ayırmaktadır. Bu bordürün üst tarafında içinde çiçeklerin yer aldığı bir kompozisyon görülmektedir. Çiçek bağının içerisinden çıkan ve her iki yönden yanlara doğru sarkan dallar, yapraklar ve rozet çiçekleri ele alınmıştır. Kitabede yer alan yazı şeritleri 11 satır halinde verilmiştir. Ayak taşı yanlardan sivri üst tepelik kısmına doğru gidildikçe genişlemektedir. Gövde yüzeyinde ucu sağa doğru kıvrık olan servinin, gövdesi alttan üste doğru genişleyen içi taralı, gövdesinin iki yanından birer dal çıkan ve bu dalların her bir tarafında birer horoz ibiği çiçeği motifi bulunan servi ağacı, taşa kazılmıştır.

\section{Mezar Taşı No 2}

Fotoğraf No: 3, 4, 5 (Fot.4, Aişe, 1885; Fot.5, Hacı Ali Efendi zevcesi Gülsüm, 1793, Büyük Mezarlık), çizim:2

Tarih: D.1868, Ö.1929

Kime Ait Olduğu: Ayşe Öğüt

Yeri: Büyük Mezarlık

Üslup: Antinatüralist verilmiştir.

Kitabesi: -Nasuhoğlu, -Hafız Mehmet, -Zevcesi, -Ayşe Öğüt, -Ruhuna, Fatiha, -D.1285, Ö.1929.

Biçimi: Dikdörtgen gövde formludur.

Bugünkü Durumu: Sağlam durumdadır.

Türü: Kadın mezarıdır.

Malzeme: Mermer malzeme kullanılmıştır. 


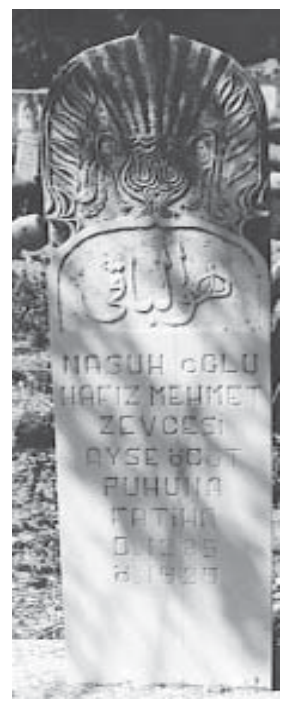

Fotoğraf 3. Ayse Öğüt, D.1868, Ö. 1929, Büyük Mezarlık

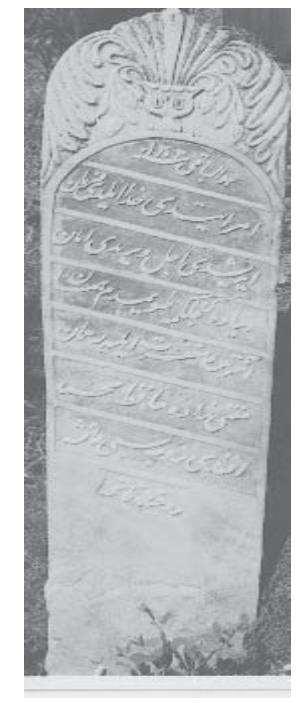

Fotoğraf 4. Müftüzade Hafiz Muhammed Efendi zevcesi Aişe, 1885 , Büyük Mezarlık

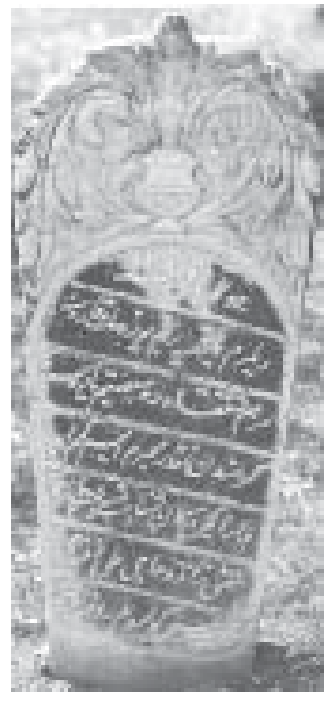

Fotoğraf 5. Müftüzade Hacı Ali Efendi zevcesi Gülsüm, 1793, Büyük Mezarlık

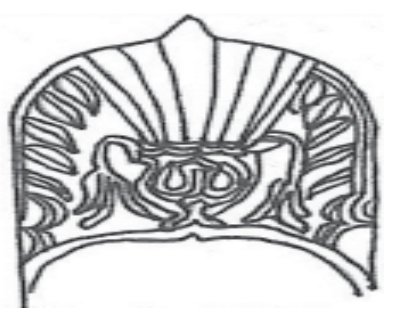

No.2, çizim 2, Ayşe Öğüt, D.1868, Ö. 1929, Büyük Mezarlık

Ölçü: Boy: 109 cm. En: $30 \mathrm{~cm}$. Kal.: $9 \mathrm{~cm}$.

Konu: Bitkisel (akantus, yaprak) ve nesneli (vazo) bezeme seçilmiştir.,

\section{Tanım ve Kompozisyon}

Alt kısımdan üst kısma doğru genişleyerek devam eden mezar taşının, gövde ile sivri tepelik kısmını basık kemer biçimli bir bordür ayırmaktadır. Bu bordürün üst tarafında kaideli bir vazo içerisinden yükselen stilize edilmiş yapraklar yer almaktadır. Vazonun gövdesi bitkisel bezemeli olup, vazodan şua şeklinde çıkan dallar üste ve yanlara doğru kıvrılmaktadır. Kitabede yer alan yazı şeritleri 7 satır halinde verilmiştir. 


\section{Mezar Taşı No 3}

Fotoğraf No: 6,7 (Fot.7, Ağazade Hacı Hafız Muhammed Ali kerimesi Hadice, 1871, Büyük Mezarlık)

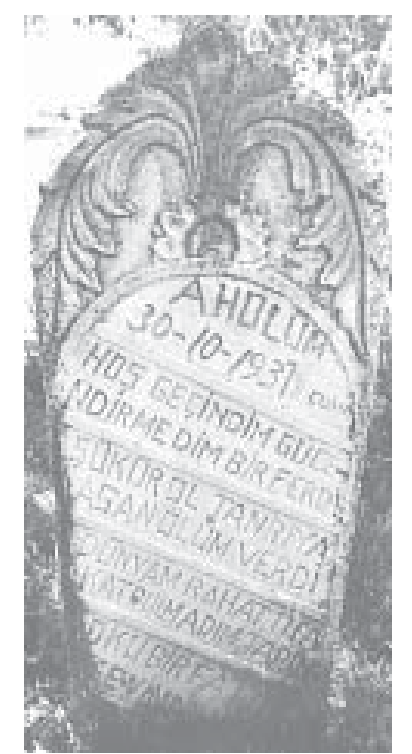

Fotoğraf 6, Hacı Hüseyin karısı Fatma ,1931, Büyük Mezarlık

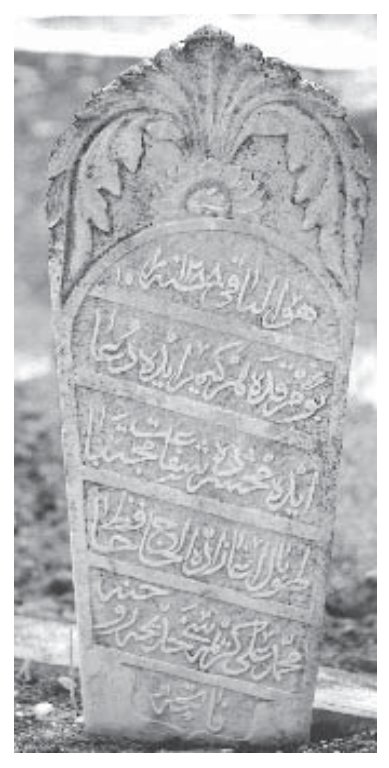

Fotoğraf 7, Ağazade Hacı

Hafız Muhammed Ali kerimesi Hadice, 1871, Büyük Mezarlık

Tarih: 30.10.1931

Kime Ait Olduğu: Hacı Hüseyin Karısı Fatma

Yeri: Büyük Mezarlık

Üslup: Antinatüralist verilmiştir.

Kitabesi: -Ah ölüm, -30.10.1931 Cuma, -Hoş geçindim, -Gücendirmedim bir ferdi, -Şükür ol Tanrı'ya asan ölüm verdi, -Dünyam rahattı, fakat bulmadım, -Tadını, oku bir fatiha, -Sevindir kadını, -Hacı Hüseyin, -Karısı Fatma, Ruhuna fatiha

Biçimi: Dikdörtgen gövde formludur.

Bugünkü Durumu: Sağlam durumdadır.

Türü: Kadın mezarıdır.

Malzeme: Mermer malzeme kullanılmıştır.

Ölçü: Boy: 119 cm. En: 47 cm. Kal.: 6 cm.

Konu: Bitkisel (akantus, ayçiçeği) seçilmiştir. 


\section{Tanım ve Kompozisyon}

Alt kısımdan üst kısma doğru her iki yönden genişleyerek devam eden mezar taşının, gövde ile sivri tepelik kısmını yuvarlak kemer biçimli bir bordür ayırmaktadır. Bu bordürün merkezine irice ayçiçeği göbeği yerleştirilmiş ve bu çiçeğin üstünde de stilize edilmiş, bukle haline getirilmiş akantus yaprakları yerleştirilmiştir. Yapraklar üste, sağa ve sola doğru kıvrılarak devam etmektedir. Kitabede yer alan yazı şeritleri 11 satır halinde verilmiştir.

Mezar Taşı No 4:

Fotoğraf No: 8

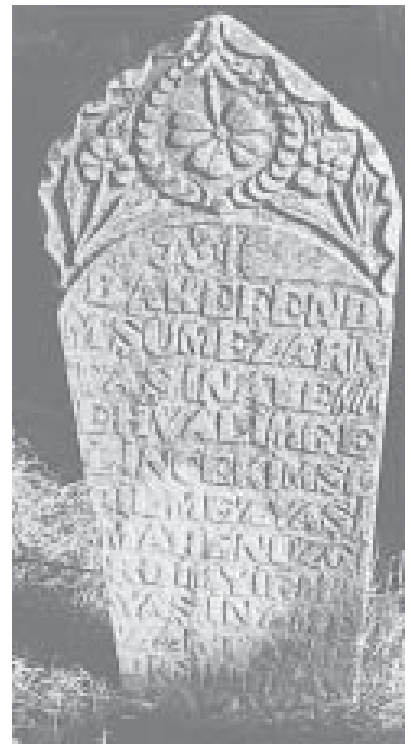

Fotoğraf .8, 1931, Ağalar Mezarlığ 1

Tarih: 1931

Kime Ait Olduğu: Belli değildir.

Yeri: A ğalar Mezarlı̆̆ 1

Üslup: Antinatüralist verilmiştir.

Kitabesi : -1931, -Bak efendi, -m şu mezarın, -Taşına, benim, -Ehvalim ge, -lince kimse, -Bilmez yaşı, -m, ah henüz gi, -rdim yirmi, -Yaşına, me, -zar taşı, -Diğildi başı, -ma.

Biçimi: Dikdörtgen gövde formludur.

Bugünkü Durumu: Sağlam durumdadır.

Türü: Kadın mezarı olabilir. 
Malzeme: Mermer malzeme kullanılmıştır.

Ölçü: Boy: 92 cm. En: 35 Kal.: 6 cm.

Konu: Bitkisel (rozet, yaprak) ve nesneli (takı) bezeme seçilmiştir.

\section{Tanım ve Kompozisyon}

Alt kısımdan üst kısma doğru genişleyerek devam eden mezar taşının, gövde ile sivri tepelik kısmını yuvarlak kemer biçimli bir bordür ayırmaktadır. Bu bordürün merkezine irice bir rozet çiçeği ve çiçeğin çevresine de takı yerleştirilmiştir. Bu takının her iki tarafına karşıllklı olarak yerleştirilmiş birer tane rozet çiçeği göze çarpmaktadır. Taşın tepeliğinin her iki kenarında stilize edilmiş ve perde bukleleri gibi verilmiş yapraklardan oluşan motifler işlenmiştir. Kitabede yer alan yazı şeritleri 13 satır halinde verilmiştir.

\section{Mezar Taşı No 5:}

Fotoğraf No: 9, 10 (Fot.10, Muhammed kızı Emine, 1760, Büyük Mezarlık)

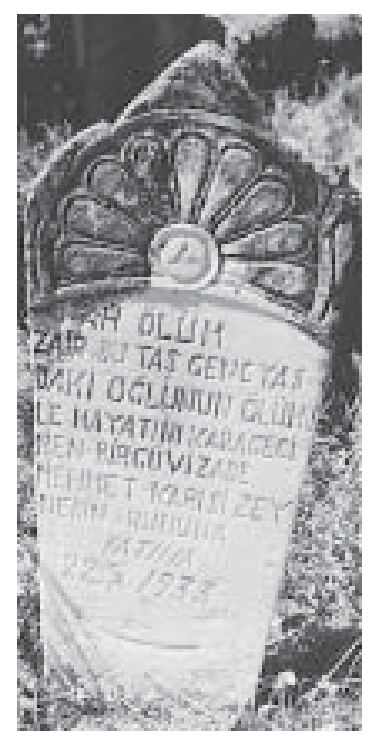

Fotoğraf 9, Zeyneb,1933, A $\breve{g} a l a r$ Mezarlığ 1

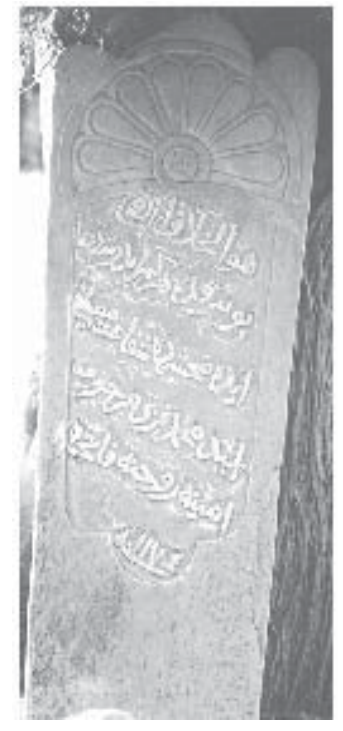

Fotoğraf 10, Muhammed kızı Emine, 1760, Büyük MezarlıkNo:7

Tarih: 22.5.1933

Kime Ait Olduğu: Birgivizade Mehmet karısı Zeyneb

Yeri: A ̆galar Mezarlığ1

Üslup: Antinatüralist verilmiştir. 
Kitabesi: -Ah ölüm, -Zair bu taş genç yaş, -Dahi oğlunun ölümü, -le hayatını kara ge, -çiren Birgivizade, -Mehmet Bey karısı Zey, -nebin ruhuna, Fatiha, -22. 5.1933.

Biçimi: Dikdörtgen gövde formludur. dadır.

Bugünkü Durumu: Ü̉ç parça çıkıntılı tepelik kısmı kırık ve eksik durum-

Türü: Kadın mezarıdır.

Malzeme: Mermer malzeme kullanılmıştır.

Ölçü: Boy: 85 cm. En: 35 Kal.:7

Konu: Bitkisel (gül,akantus) ve geometrik (damla veya 1şın çubuğu) bezeme seçilmiştir.

\section{Tanım ve Kompozisyon}

Alt kısımdan üst kısma doğru genişleyerek devam eden mezar taşının, gövde ile dilimli tepelik kısmını basık kemer biçimli bir silme kesmektedir. Bu silmeyle birleşen ve yuvarlak kemer biçimli silmenin altında stilize edilmiş gül goncasını hatırlatan bir çiçek ve bu çiçeğin üst tarafında etrafa bir şua gibi dağılan dokuz dilimli, yelpaze, yarım rozet çiçeği, istiridye veya damla motifi gibi de tanımlayabileceğimiz ışın çubukları motifi göze çarpmaktadır. Kitabede yer alan yazı şeritleri 9 satır halinde verilmiştir.

Mezar Taşı No 6:

Fotoğraf No: 11-12

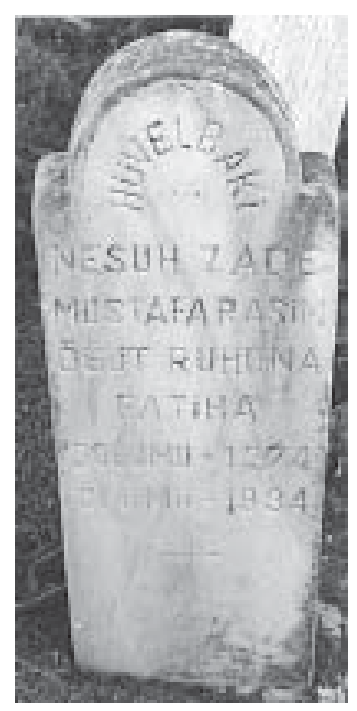

Fotoğraf 11, Mustafa Rasim Öğüt,D.1857, Ö.1934, baştaşı, Büyük Mezarlık

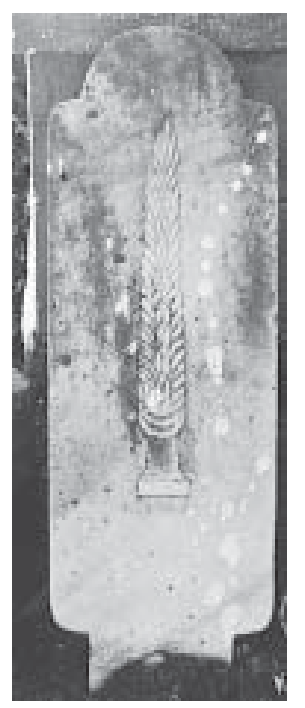

Fotoğraf 12, Mustafa Rasim Öğüt,D.1857, Ö.1934, ayaktaş1, Büyük Mezarlık 
Tarih: D.1857, Ö.1934

Kime Ait Olduğu: Mustafa Rasim Öğüt

Yeri: Büyük Mezarlık

Üslup: Antinatüralist verilmiştir. ha,

Kitabesi: -Hüvel baki, -Nasuh zade, -Mustafa Rasim, -Ögüut ruhuna, -Fati-

-Doğumu -1274, Ölümü-1934.

Biçimi: Dikdörtgen gövde formludur.

Bugünkü Durumu: Sağlam durumdadır.

Türü: Erkek mezarıdır.

Malzeme: Mermer malzeme kullanılmıştır.

Ölçü: Baştaşı Boy: 85 cm. En: 33 Kal.: 9, Ayaktaşı Boy: 92, En:33, Kal.: 7

Konu: Bitkisel (servi) bezeme seçilmiştir.

\section{Tanım ve Kompozisyon}

Üst kısmı yuvarlak kemer biçimli, alt kısmı dikdörtgen gövde biçimli olan baştaşında herhangi bir süsleme bulunmamaktadır. Ayaktaşı da aynı biçime sahiptir.Taşın gövdesinde alttan üste doğru giden, içi ayrıntılı ve sık bir şekilde taranmış bir servi ağacı yer almaktadır. Kitabede yer alan yazı şeritleri 7 satır halinde verilmiștir.

\section{Mezar Taşı No 7}

Fotoğraf No: 13-14, 15 (Fot.15, Ali Ustaoğlu İsmail'in zevcesi Ümmü Gülsüm, 1848, Büyük Mezarlık), çizim:3

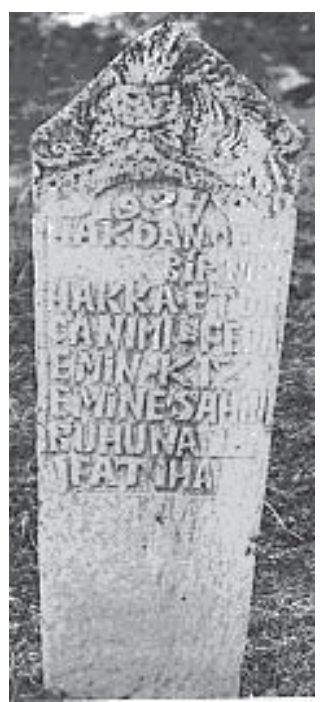

Fotoğraf 13,

Emine Şahin,

1934, baştaş1,

Büyük Mezarlık

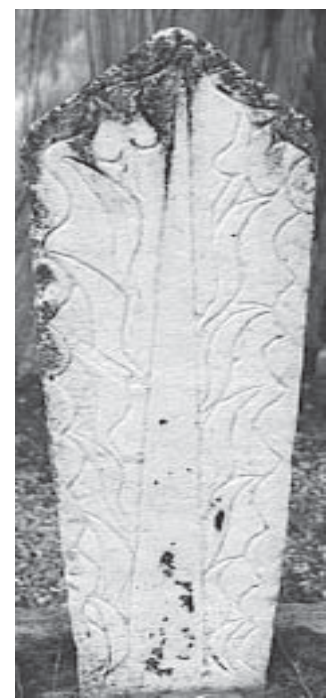

Fotoğraf 14, Emine

Şahin, 1934,

ayaktaşı, Büyük

Mezarlık 


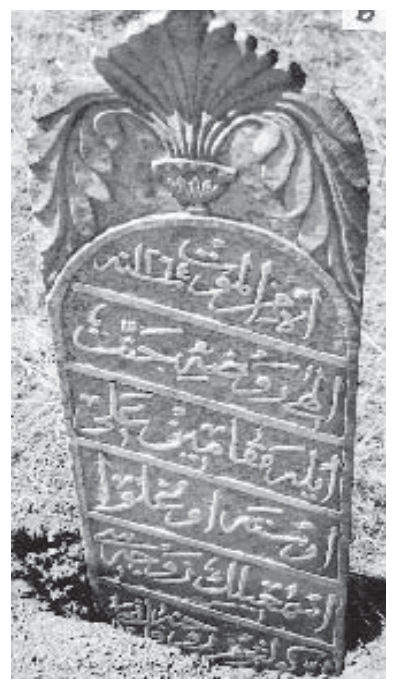

Fotoğraf 15, Ali Ustaoğlu İsmail'in zevcesi Ümmü Gülsüm, 1848, Büyük Mezarlık

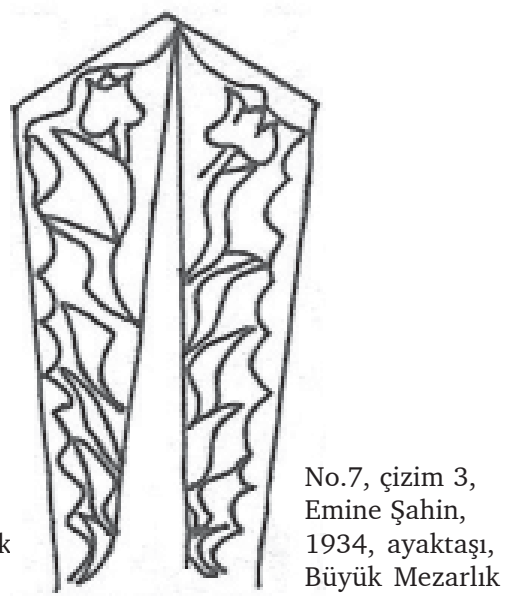

Tarih: 1934

Kime Ait Olduğu: Emin kızı Emine Şahin

Yeri: Büyük Mezarlık

Üslup: Antinatüralist ve çizgisel verilmiştir.

Kitabesi: -1934, -Hakdan geldi, -Bir nida, -Hakka etdim, -Canımı feda, Emin kızı, -Emine Şahin, -Ruhuna, -Fatiha.

Biçimi: Dikdörtgen gövde formludur.

Bugünkü Durumu: Sağlam durumdadır.

Türü: Kadın mezarıdır.

Malzeme: Mermer malzeme kullanılmıştır.

Ölçü: Baştaşı Boy: 105 cm. En: 32 Kal.: 4, Ayaktaşı Boy: 104, En:28, Kal.: 4

Konu: Bitkisel (akantus, servi, lale, yaprak) ve nesneli (vazo) bezeme seçilmiştir.

\section{Tanım ve Kompozisyon}

Alt kısımdan üst kısma doğru genişleyerek devam eden mezar taşının, gövde ile sivri tepelik kısmını yuvarlak kemer biçimli bir bordür ayırmaktadır. Bu bordürün üst tarafında kaideli bir vazo içerisinden yükselen stilize edilmiş yapraklar yer almaktadır. Vazonun gövdesi fazla belli olmamakla birlikte bezemeli olup, vazodan çıkan dallar üste ve yanlara doğru kıvrılmaktadır. Kitabede yer alan yazı şeritleri 9 satır halinde verilmiştir. Baştaşı 
ile aynı biçime sahip olan ayaktaşında alttan üste doğru giden bir servi ağacı ve servi ağacının iki yanında alttan üste doğru devam eden, oldukça stilize edilmiş ve çizgisel olarak ince bir kazımayla ele alınmış dallar, yapraklar ile servinin üst iki yanında birer laleden oluşan kompozisyon göze çarpmaktadır.

\section{Mezar Taşı No 8}

Fotoğraf No: 16-17, 18 (Fot.18 ve çizim:5, Muhammed Ağa kerimesi Rahime, 1795, Büyük Mezarlık), çizim:4, 5

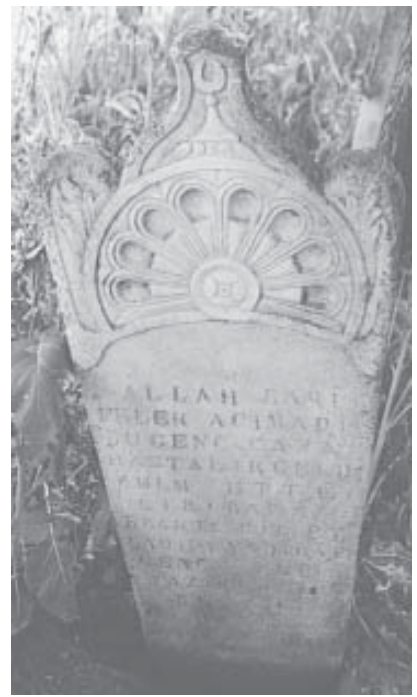

Fotoğraf 16, Kadriye Hanım,1938, baştaşı, Büyük Mezarlik

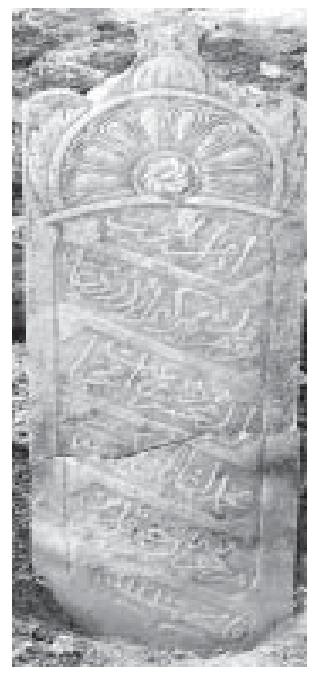

Fotoğraf 18, Muhammed Ağa kerimesi Rahime, 1795, Büyük Mezarlık

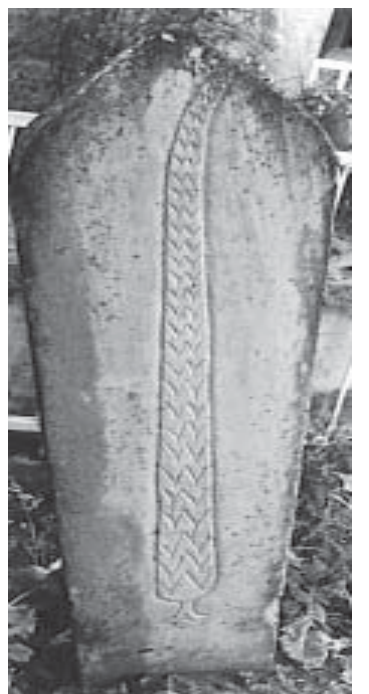

Fotoğraf 17, Kadriye

Hanım,1 938, ayaktaş1,

Büyük Mezarlık

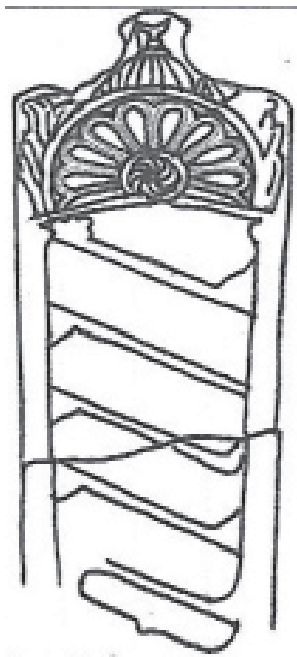

Çizim 5, Muhammed Ağa kerimesi Rahime, 1795, Büyük Mezarlık 
Tarih: 1938

Kime Ait Olduğu: Kadriye Hanım

Yeri: Büyük Mezarlık

Üslup: Antinatüralist verilmiștir.

Kitabesi: -Allah baki, -Felek acımadı, -Bu genç cana, -Zulm etti, -Giribana, -Bıraktı bir evladını, -Yadiğar, -Genç oldu, -Yazık oldu, -Bu cana, -İbrahim Büke,

-Karıs1 Kadriye, -Ruhuna fatiha, -1.12.1938.

Biçimi: Dikdörtgen gövde formludur.

Bugünkü Durumu: Sağlam durumdadır.

Türü: Kadın mezarıdır.

Malzeme: Mermer malzeme kullanılmıştır.

Ölçü: Baştaşı Boy: 110 cm. En: 40 Kal.: 6 cm., Ayaktaşı Boy: 115 cm., En:31 cm., Kal.: $7 \mathrm{~cm}$.

Konu: Bitkisel (akantus, servi, gül), nesneli (alem) ve geometrik (1şın çubukları) bezeme seçilmiştir.

Tanım ve Kompozisyon

Alt kısımdan üst kısma doğru genişleyerek devam eden mezar taşının, gövde ile dilimli tepelik kısmını basık kavisli kemer biçimli bir bordür ayırmaktadır. Bu bordürle birleşen ve yuvarlak kemer biçimli başka bir bordürün içinde stilize edilmiş gül goncasını hatırlatan bir çiçek ve bu çiçeğin etrafında sekiz dilimli yelpaze veya damla motifi gibi görünümlü ışın çubukları motifi dikkat çekmektedir. Bordürün üstünde, alemi hilalli, bir cami kubbesi, iki yanında ise; stilize edilmiş birer akantus yaprağı göze çarpmaktadır. Kitabede yer alan yazı şeritleri 14 satır halinde verilmiştir. Ayaktaşı da baştaşıyla aynı biçime sahiptir.Taşın gövdesinde alttan üste doğru giden, ucu sağa kıvrık, içi sık bir şekilde taranmış bir servi ağacı yer almaktadır.

\section{Mezar Taşı No 9:}

Fotoğraf No: 19, çizim:6

Tarih: 11.4.1939

Kime Ait Olduğu: Hacı Ahmet karısı Gülsüm Özkan

Yeri: Büyük Mezarlık

Üslup: Antinatüralist verilmiştir.

Kitabesi: -Muhamme'de, -Kandım, -Tan, -rı'ya inandım, -Dünya yalan, mış gafil av, -landım, -Hacı Ahmet, -Karısı, -Gülsüm Özkan, -Ruhuna, -Fatiha, -11 Nisan 1939.

Biçimi: Dikdörtgen gövde formludur. 

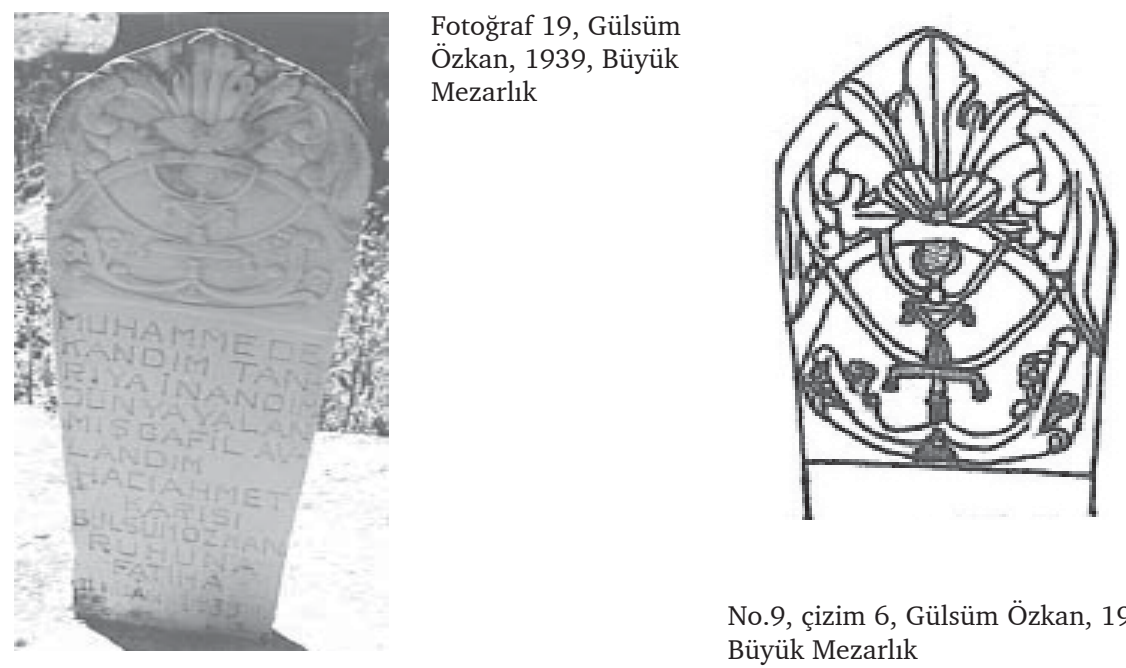

No.9, çizim 6, Gülsüm Özkan, 1939, Büyük Mezarlık

Bugünkü Durumu: Sağlam durumdadır.

Türü: Kadın mezarıdır.

Malzeme: Mermer malzeme kullanılmıştır.

Ölçü: Boy: $101 \mathrm{~cm}$. En: $30 \mathrm{~cm}$. Kal.: $6 \mathrm{~cm}$.

Konu: Bitkisel (akantus, rozet, küpe) ve geometrik (püskül, zincir, apolet) bezeme seçilmiştir.

\section{Tanım ve Kompozisyon}

Sivri kemer biçimli tepelikli, dikdörtgen gövde biçimli olan taşın tepeliğinde, vazoya benzetilmiş bitkisel bir motifin içerisinden stilize edilmiş akantus yaprakları ve yaprakların arasından birer küpe çiçeği çıkmaktadır. Tepeliği sınırlayan basık kemer biçimli bordürle, yazı şeritlerini kesen yatay bordür arasındaki kısımda bitkisel ve nesneli motifler göze çarpmaktadır.Bunun üst tarafında dairesel bir nesnenin içerisinde rozet çiçeği bulunmaktadır. Onunda altında iki tane apolete benzer püsküllü bir nesne dikkat çekmektedir. Bunun üzerinde ve altında yarı dairesel ve kordonu andırır bir zincir iki taraftan bordürle birleşmektedir. Alt kısımda yine apolete benzer bir nesne işlenmiştir. Daha da altta ise, bir püskülün altından çıkan stilize edilmiş yapraklar ve çiçeklerden oluşan bir bezeme dikkat çekmekte ve bunlar iki ters yöne doğru karşılıklı olarak sıralanmaktadır. Kitabede yer alan yazı şeritleri 13 satır halinde verilmiştir. 


\section{Mezar Taşı No 10:}

Fotoğraf No: 20-21, 22 (Fot.22, Topal Ağazade Muhammed Ali Ağanın ehli Aişe, 1854, Büyük Mezarlık)

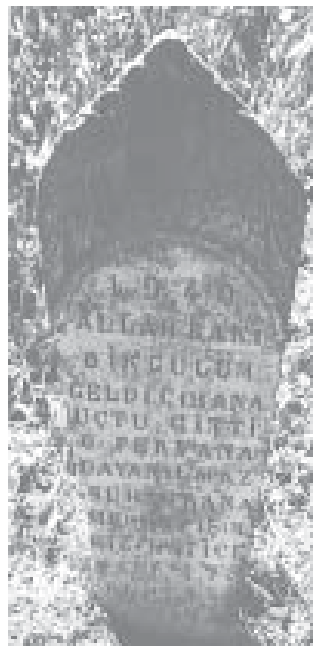

Fotoğraf 20, Hatice, 1940, baştaş1, Büyük Mezarlık

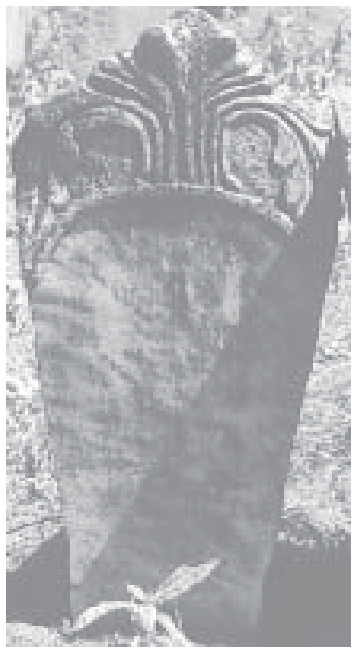

Fotoğraf 21, Hatice, 1940, ayaktaşı, Büyük Mezarlık

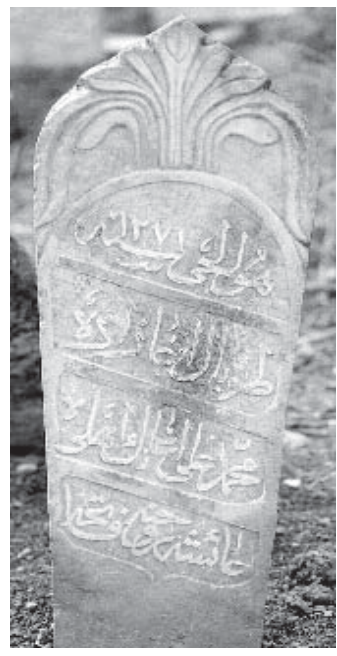

Fotoğraf 22, Topal Ağazade Muhammed Ali Ağanın ehli Aişe, 1854, Büyük Mezarlık

Tarih: 1940

Kime Ait Olduğu: Mehmet Işık kızı Hatice

Kitabesi: -1940, -Allah baki, -Bir gülüm, -Geldi cihana, -Uçtu gitti, -O pervana, -Dayanılmaz, -Bu hicrana, -Mehmet Işık, -Kızı Hatice, -Yaşı 17,Ruhuna, - Fatiha.

Biçimi: Dikdörtgen gövde formludur.

Bugünkü Durumu: Sağlam durumdadır.

Türü: Kadın mezarıdır.

Malzeme: Mermer malzeme kullanılmıştır.

Ölçü: Baştaşı Boy: 93 cm. En: 32 Kal.: 7 cm., Ayaktaşı Boy: 93, En:31 cm., Kal.: $5 \mathrm{~cm}$.

Konu: Bitkisel (akantus, yaprak) bezeme seçilmiştir.

\section{Tanım ve Kompozisyon}

Baştaşı ve ayaktaşı alttan üste doğru genişleyen, dikdörtgen gövde formlu, üst kısımları sivri kemer biçimli bir şekilde ele alınmıştır. Baştaşının üst 
tepelik kısmında, vazo biçimine getirilmiş bitkisel unsurlu bir motifin içerisinden çıkan stilize edilmiş dallar ve yapraklar göze çarpmaktadır. Yazının bulunduğu kısımla tepelik kısmın yuvarlak kemer biçimli bir bordür ayırmaktadır. Kitabede yer alan yazı şeritleri 13 satır halinde verilmiştir. Ayaktaşında yer alan süslemeyi stilize edilmiş akantuslar oluşturmaktadır. Akantuslar üste ve iki yöne doğru kıvrılmaktadır. Akantusun yer aldığı tepelik kısmı ile herhangi bir süsleme bulunmayan gövde kısmını yuvarlak kemer biçimli bir bordür kesmektedir.

\section{Mezar Taşı No 11}

Fotoğraf No: 23-24, çizim:7

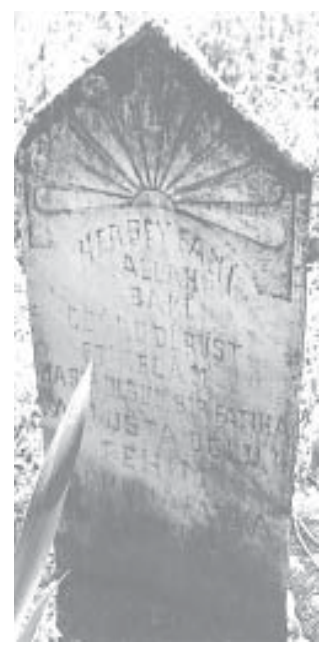

Fotoğraf 23, Ali

Ustaoğlu Fehim, 1941, baştaşı, Büyük Mezarlık

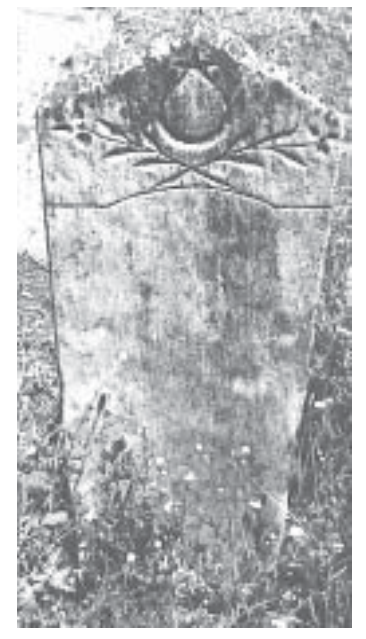

Fotoğraf 24, Ali Ustaoğlu Fehim, 1941, ayaktaş1, Büyük Mezarlık

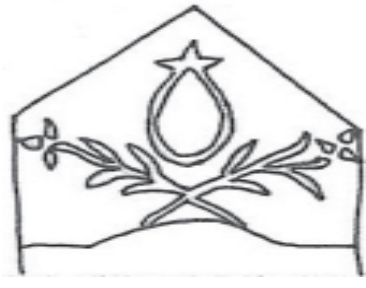

No.11, çiz.im 7, Ali Ustaoğlu Fehim, 1941, ayaktaşı, Büyük Mezarlık

Tarih: 3.2.1941

Kime Ait Olduğu: Ali Ustaoğlu Fehim

Yeri: Büyük Mezarlık

Üslup: Antinatüralist verilmiştir.

Kitabesi: -Her şey fani, -Allah, -Baki, -Doğru dürüst, -Et kelam, -Nasip olsun bir fatiha, -Ali Ustaoğlu, -Fehim, -Ruhuna fatiha, -3.2.1941.

Biçimi: Dikdörtgen gövde formludur.

Bugünkü Durumu: Sağlam durumdadır. 
Türü: Erkek mezarıdır.

Malzeme: Mermer malzeme kullanılmıștır.

Ölçü: Baştaşı Boy: 86 cm. En: 41 cm. Kal.: 4 cm., Ayaktaşı Boy: 79 cm., En: 29 cm., Kal.: $7 \mathrm{~cm}$.

Konu: Bitkisel (kıvrık dal) ve geometrik (ışın çubuğu, hilal, yıldız) bezeme seçilmiştir.

\section{Tanım ve Kompozisyon}

Baştaşı ve ayaktaşı alttan üste doğru genişleyen, dikdörtgen gövde formlu, sivri kemer biçimli tepelikle bir şekilde ele alınmıştır. Baştaşının üst tarafında alttan istiridye nişi, damla, yelpaze diye de adlandırılan ışın çubukları motifi göze çarpmaktadır. Kitabede yer alan yazı şeritleri 10 satır halinde verilmiştir. Ayaktaşının üst kısmında yer alan bezeme ise; birbirini alttan kesen iki yapraklı dal üstünde hilal ve yıldız motifleri tasvir edilmiştir. Gövde yüzeyi ince bir çizgi halinde yatay ve yuvarlak kemer biçimli bir şekilde kesilmiştir. Gövde de herhangi bir süsleme bulunmamaktadır.

Mezar Taşı No 12:

Fotoğraf No: 25

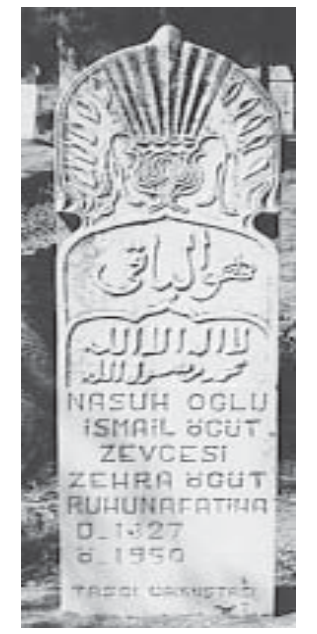

Fotoğraf 25, Zehra Öğüt, D.1909, Ö.1950, Büyük Mezarlık

Tarih: D.1909, Ö.1950

Kime Ait Olduğu: Nasuhoğlu İsmail Öğüt zevcesi Zehra Öğüt Yeri: Büyük Mezarlık

Üslup: Antinatüralist verilmiştir. 
Kitabesi: -Hüvel baki, -La ilahe illallah, -Muhammeden Resullullah, -Nasuh oğlu, -İsmail Öğüt, -Zevcesi, -Zehra Öğüt, -Ruhuna fatiha, -D.1327, Ö.1950, -Taşçı cami ustası

Biçimi: Dikdörtgen gövde formludur.

Bugünkü Durumu: Sağlam durumdadır.

Türü: Kadın mezarıdır.

Malzeme: Mermer malzeme kullanılmıştır.

Ölçü: Boy: $110 \mathrm{~cm}$. En: $31 \mathrm{~cm}$. Kal.: $9 \mathrm{~cm}$.

Konu: Bitkisel (akantus, yaprak) ve nesneli (vazo) bezeme seçilmiştir.

\section{Tanım ve Kompozisyon}

Alt kısımdan üst kısma doğru genişleyerek devam eden mezar taşının, gövde ile yuvarlak tepelik kısmını basık kemer biçimli bir bordür ayırmaktadır. Bu bordürün üst tarafında kaideli bir vazo içerisinden yükselen stilize edilmiş yapraklar yer almaktadır. Vazonun gövdesi bitkisel bezemeli olup, vazodan çıkan şua şeklinde çıkan dallar üste ve yanlara doğru kıvrılmaktadır. Kitabede yer alan yazı şeritleri 11 satır halinde verilmiştir.

\section{Mezar Taşı No 13:}

Fotoğraf No: 26-27

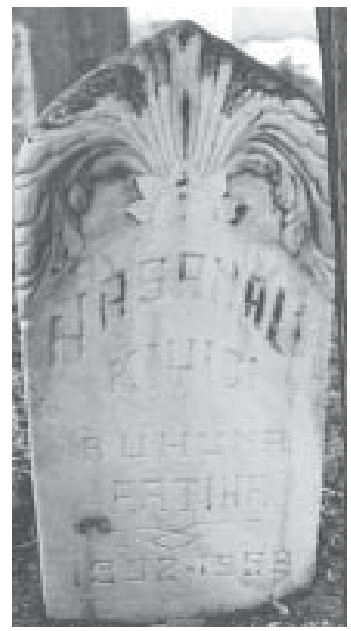

Fotoğraf 26, Hasan Ali Kiyıc1, 1902-1959, baştaşı, Büyük Mezarlık

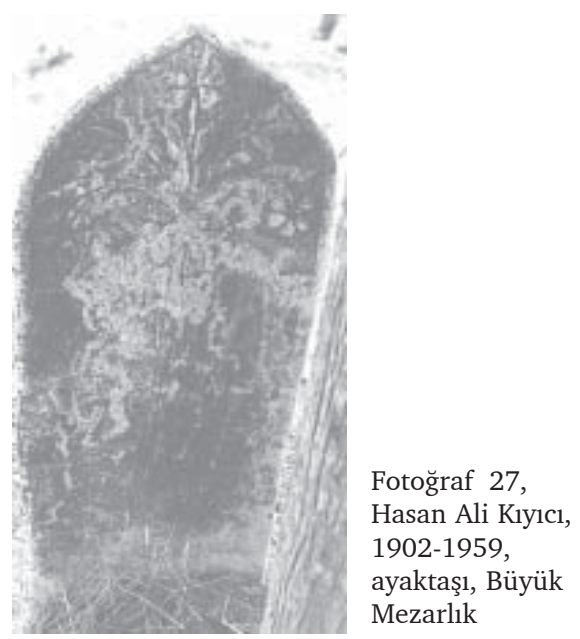

Tarih: 1902-1959

Kime Ait Olduğu: Hasan Ali Kiyıcı

Yeri: Büyük Mezarlık

Üslup: Antinatüralist verilmiştir. 
Kitabesi: -Hasan Ali, -Kıyıc1, -Ruhuna, -Fatiha, -1902-1959.

Biçimi: Dikdörtgen gövde formludur.

Bugünkü Durumu: Sağlam durumdadır.

Türü: Erkek mezarıdır.

Malzeme: Mermer malzeme kullanılmıştır.

Ölçü: Baştaşı Boy: 83 cm. En: 36 cm. Kal.: 6 cm., Ayaktaşı Boy: 80 cm., En:39, Kal.: $5 \mathrm{~cm}$.

Konu: Bitkisel (akantus, ayçiçeği, servi, rozet, yaprak) bezeme seçilmiştir.

\section{Tanım ve Kompozisyon}

Alt kısımdan üst kısma doğru her iki yönden genişleyerek devam eden baştaşı ve ayaktaşının, gövde ile sivri tepelik kısmını yuvarlak kemer biçimli bir çizgiyle ayrılmaktadır. Baştaşının üst merkezine irice ayçiçeği göbeği konulmuş ve bu çiçeğin üstünde de stilize edilmiş, bukle haline getirilmiş akantus yaprakları yerleştirilmiştir. Yapraklar üste, sağa ve sola doğru kıvrılarak devam ettiği görülmektedir. Kitabede yer alan yazı şeritleri 5 satır halinde verilmiştir. Ayaktaşının üst kısmında kıvrık dallı yapraklar ve bazılarının üzerinde rozet çiçekleri göze çarpmaktadır. Taşın gövde yüzeyinde ise; ucu sağa doğru kıvrık bir servi ağacı tasvir edilmiştir.

\section{Mezar Taşı No 14:}

Fotoğraf No: 28-29, çizim:8-9

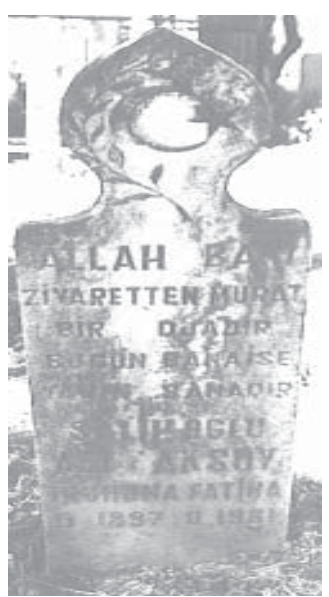

Fotoğraf 28, Salihoğlu Ali Aksoy, 1897-1961, baştaş1, Hüseyni Baba Mezarlığı

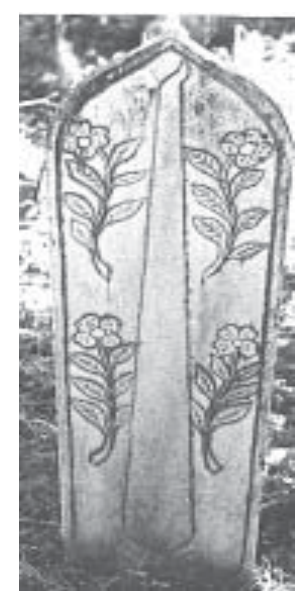

Fotoğraf 29, Salihoğlu Ali Aksoy, 1897-1961, ayaktaş1, Hüseyni Baba Mezarlığı 


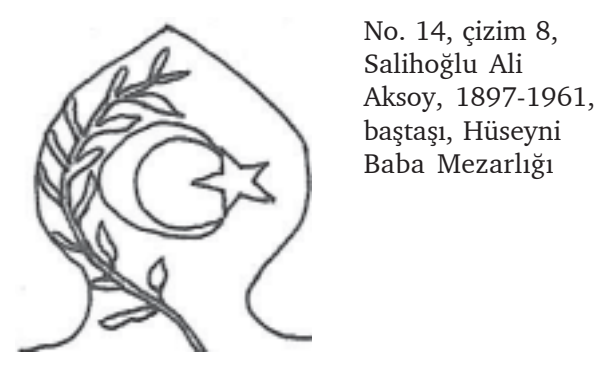

Tarih: D.1897, Ö.1961

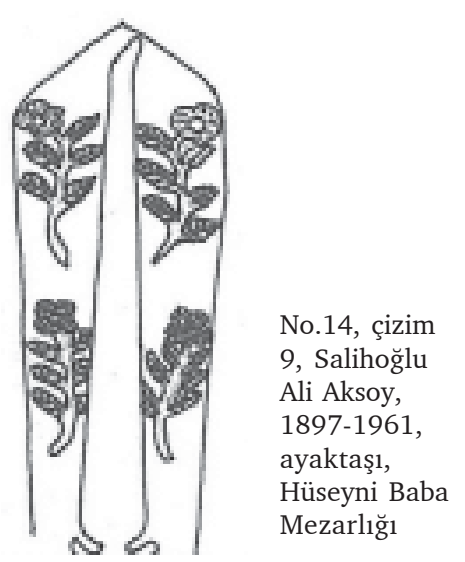

Kime Ait Olduğu: Salihoğlu Ali Aksoy

Yeri: Hüseyni Baba Mezarlı̆̆ 1

Kitabesi: -Allah baki, -Ziyaretten murat, -Bir duadır, -Bugün bana ise, Yarın sanadır, -Salihoğlu, -Ali Aksoy, -Ruhuna fatiha, -D.1897, Ö.1961.

Biçimi: Dikdörtgen gövde formludur.

Bugünkü Durumu: Sağlam durumdadır.

Türü: Erkek mezarıdır.

Malzeme: Mermer malzeme kullanılmıştır.

Ölçü: Baştaşı Boy: 86 cm. En: 28 cm. Kal.: 4 cm., Ayaktaşı Boy: 90 cm., En:29 cm., Kal.: $4 \mathrm{~cm}$.

Konu: Bitkisel (kıvrık dal, servi, rozet) ve geometrik (hilal, yıldız) bezeme seçilmiştir.

\section{Tanım ve Kompozisyon}

Baştaşı ve ayaktaşı üstten alta doğru gidildikçe inceleşen, dikdörtgene yakın gövde formludur. Baştaşının insan başı gibi verilmiş dairesel üst kısmında bir kıvrık dalın kuşattığı hilal ve yıldız şeklinde tasvir görülmektedir. Kitabede yer alan yazı şeritleri 9 satır halinde verilmiştir. Ayaktaşında ise ucu sağa kıvrık bir servi ağacı ile bu servi ağacının alt ve üst her iki yanına S kıvrımı yapan dallar üzerine, karşılıklı yerleştirilmiş, stilize edilmiş rozet çiçeğinden oluşan bir betimleme görülmektedir. Bezeme hafif bir kazımayla verilmiş olup, oldukça yüzeysel görünümdedir.

\section{Değerlendirme ve Karşılaştırma}

Makalemizde tanıtmaya çalıştığımız mezar taşlarından 13 tanesi Cumhuriyet döneminden, 1961 yılına kadar yapılmış, geçmişten izler taşıyan örneklerdir. Bir örnek ise Osmanlının son döneminde yapılmış (1916) ancak, yeni 
yazının kabulünden sonra taşın yüzeyi silinerek veya başka bir taş kullanılarak yeni Türkçe ile yazılmış olabilmesi ihtimali ile araştırmamıza dahil edilmiştir. 14 örnek 1916 ile 1961 yılları arasındaki bir zaman dilimini kapsamaktadır. Şahidelerin boyları $82 \mathrm{~cm}$. ile $119 \mathrm{~cm}$., enleri $28 \mathrm{~cm}$. ile $47 \mathrm{~cm}$., kalınlıkları $4 \mathrm{~cm}$. ile $9 \mathrm{~cm}$. arasında değişmektedir. 9 mezar taşı kadınlara ait, 4 mezar taşı erkeklere ait, 1 mezar taşı da (no: 4) kime ait olduğu bilinmemekle birlikte süsleme özelliklerinden dolayı bir kadına ait mezar olabileceği söylenebilir . 9 mezar taşı ayak taşlıdır ancak 1 tanesi (No:9) süssüz veya sade olduğu için o ayak taşı ele alınmamıştır. 5 mezar taşında ölüm tarihi yanında doğum tarihi ve 2 mezar taşında da kaç yaşında öldügüu tarih de yazıyla verilmiştir. Doğum tarihinin verilmesi Gördes Osmanlı mezar taşlarında çok görülen bir hususiyet değildir. Bu daha çok Cumhuriyet dönemi ile birlikte daha sık karşılaşabildiğimiz özelliklerden biridir.

Yeni Türkçe ile verilmiş yazılar, taşın yüzeyi oyularak, kabartma görünümünde ve bazıları da ince bir şekilde kazılarak ortaya çıkarılmış vaziyettedir. Şahidelerin 2 tanesi Ağalar Mezarlığından, 11 tanesi Büyük Mezarlıktan, 1 tanesi Hüseyni Baba Mezarlığındandır. Örneklerin hepsinde mermer malzeme kullanılmıştır. İki mezar taşında (No-2 ve 12) yeni yazıyla birlikte Arap alfabeli yazılar da verilmiştir. Mezar taşlarından No: 1, 3, 5, 8, 10, 13 diye adlandırdığımız şahidelerin Osmanlı döneminde daha önceden kullanılmış olma ihtimali yüksektir. Çünkü yakın tarihli mezar taşları ile Osmanlı dönemi mezar taşlarında kullanılan mermer arasında belirgin fark görülmektedir. Ayrıca tekrar kullanılmış taşların yüzeyinde silme neticesi oluşmuş, gözle görülür bir parlaklık ve incelmişlik göze batmaktadır. İlk defa Gördes mezarlıklarında Cumhuriyet dönemine ait (no-9'da) bir mezar taşında taşçı cami ustası diye meslek belirten bir ibare geçmektedir. Osmanlı döneminde Gördes'te yerel taşçı ustalarının varlı̆̆ 1 tahmin edilmekle birlikte incelenen Osmanlı dönemi mezar taşları arasında taşçı ustası ile ilgili bir ibareyle karşılaşılamamıştır ${ }^{8}$.

Mezar taşlarında bezeme olarak bitkisel, nesneli ve geometrik süslemeler görülmektedir. Bezemelerin çoğu, Osmanlı dönemindeki mezar taşlarında ve su mimarisi içerisinde yer alan benzer özelliklere sahiptir ${ }^{9}$. İnceledi-

$8 \quad$ Bkz. H. Kamil Biçici, a.g.t., 812-816.

9 Özellikle su mimarisi içinde yer alan çeşmelerde, şadırvanlarda, sebillerde karşımıza çıkan bezemelerde işlenen motifler mezar taşlarında sıkça görülmektedir. Bu bezemelerle ilgili olarak çok çeşitli yayınlar ve çalışmalar bulunmaktadır. Bkz. B.Aktuna, Ankara Çeşmeleri (G.Ü.FenEdebiyat Fakültesi Arkeoloji-Sanat Tarihi Anabilim Dalı Yayınlanmamış Lisans Tezi), Ankara 1997; Anonim, Tarihi Sinop Çeşmeleri, Sinop 1990;H.Aynur-H.T.Karateke, III. Ahmed Devri İstanbul Çeşmeleri, İstanbul 1995; A. Aytöre, “Türkler'de Su Mimarisi”, Milletlerarası Birinci Türk 
ğimiz bitkisel bezemeli şahideler içinde yaprak motifi ( 8 mezar taşında), ayçiçeği (2 mezar taşında), rozet (5 mezar taşında), horoz ibiği (1 mezar taşında), akantus (9 mezar taşında), servi (6 mezar taşında), kıvrık dal (2 mezar taşında), küpe (1 mezar taşında), gül (1 mezar taşında), lale (1 mezar taşında) işlenmiștir. Geometrik bezemeler içinde yıldız (2 mezar taşında), hilal (2 mezar taşında), 1şın çubuğu (3 mezar taşında) betimlenmiştir. Nesneli bezemeler içinde ise; çiçek bağı (1 mezar taşında), vazo (3 mezar taşında), zincir (1mezar taşında), püskül (1 mezar taşında), apolet (1 mezar taşında), takı (1 mezar taşında), alem (1 mezar taşında) dikkat çekmektedir.

Gördes mezar taşlarında sıkça görülen bezemelerden olan servi Osmanlı sanatının neredeyse her kolunda sevilerek kullanılmış ve servi motifli eşsiz eserler yapılmıştır. Türk sanatında minyatürde, tezhipte, kitap kapları şemselerinde, kağıt oyma süslerde, servi şekilli yazılarda, maden eşyada, nakış ve resimde, seramikte, taş işçilikte, mimaride, çeşmelerde ${ }^{10}$, mezar

Sanatları Kongresi, Kongreye Sunulan Tebliğler (Ankara 19-24 Ekim 1959), Ankara 1962, S. 45 69; T. Bozkurt, Beypazarı'ndaki Türk Devri Yapıları, Ankara 2004; A. Çaylak, Çanakkale Çeşmeleri (G.Ü.Sosyal Bilimler Enstitüsü Sanat Tarihi Anabilim Dalı Yayınlanmamış Yüksek Lisans Tezi), Ankara 1997; K. Çeçen, İstanbul'da Osmanlı Devrindeki Su Tesisleri, İstanbul 1984; K. Çeçen, Mimar Sinan ve Kırk Çeşme Tesisleri, İstanbul 1988; K.Çeçen, Halkalı Suları, İstanbul 1991; K. Çeçen, Üsküdar Suları, İstanbul 1991; M.Çerkez, “Ayaş Yunak ve Çeşmeleri”, Ayaş ve Çevresi Kültür-Sanat Araştırmaları Sempozyumu Bildirileri (2-3 Mayıs 1997 Ayaş), Ayaş, S. 199-233; M. Çerkez, "Beypazarı Çeşmeleri”, Cumhuriyetin 80. Yılında Her Yönüyle Ankara, Ankara 2004, S. 241-252; S. Çetintaş, "Türklerde Su, Sebil, Çeşme”, Güzel Sanatlar Dergisi, C.V, İstanbul 1944, S. 124-145; Y. Demiralp, Akşehir ve Köylerindeki Türk Anıtları, Ankara 1996; M.Denktaş, Karaman Çeşmeleri, Kayseri 2000; M. Denktaş, Kayseri'deki Tarihi Su Yapıları (Çeşmeler ve Hamamlar), Kayseri 2000; A. Egemen, İstanbul'un Çeşme ve Sebilleri, İstanbul 1993; İ. Kuyulu, Kara Osman-Oğlu Ailesine Ait Mimari Eserler, Ankara 1992; A. C.Kürkçüoğlu, Şanlıurfa Su Mimarisi, Ankara 1993; A. Ödekan, "Kent İçi Çeşme Tasarımında Tipolojik Çözümleme”, Semavi Eyice’ye Armağan, İstanbul Yazıları, İstanbul 1992, S. 281-297; M. Önder, Konya Çeşme ve Şadırvanları, Konya 1955; Y. Önge, Türk Mimarisinde Selçuklu ve Osmanlı Dönemlerinde Su Yapıları, Ankara 1997; E. Özdeniz, İstanbul'daki Kaptan-I Deryâ Çeşmeleri ve Sebilleri, İstanbul 1995; Ş. Öztürk, Bitlis Su Mimarisi, Malatya 2004; A. Özünal, Bergama Tarihinde Su Yolları ve Çeşmeler, Bergama 1997; N. K. Pilehvarian, Osmanlı Başkenti İstanbul'da Çeşmeler, İstanbul 2000; N. K. Pilehvarian, "Osmanlı Çeşme Mimarisinde XIX. Yüzyıl Değişimleri”, Tarihi, Kültürü ve Sanatıyla Iv. Eyüpsultan Sempozyumu, Tebliğler (5-7 Mayıs 2000), İstanbul 2000, S. 68-75; İ.H.Tanışık, İstanbul Çeşmeleri, C. I, İstanbul 1943; İ. H. Tanışık, İstanbul Çeşmeleri, C. II, İstanbul 1945; S. Tansuğg, "XVIII. Yüzyılda İstanbul Çeşmeleri ve Ayasofya Şadırvanı", Vakıflar Dergisi, S. 6, İstanbul 1965, S. 93-110; Ö. Yörükoğlu, Kayseri Çeşmeleri, Kayseri 1987; H. Yurttaş-H.Özkan, Tarihi Erzurum Çeşmeleri ve Su Yolları, Erzurum 2002; N. Yüngül, Taksim Suyu Tesisleri, İstanbul 1957.

10 Bkz. H. Örcün Barışta, İstanbul Çeşmeleri, Beyoğlu Cihetindeki Meyve Tabağı Motifleriyle Bezenmiş Tek Cepheli Anıt Çeşmeleri: Kaptan Hüseyin Paşa Çeşmesi, Topçubaşı İsmail Ağa Çeşmesi, Kemankeş Çeşmesi, Kültür Bakanlığı Yayınları, Ankara 1991; H. Örcün Barışta, Ortaköy Damat İbrahim Paşa Çeşmesi- Hacı Mehmet Ağa Çeşmesi-Taksim Maksemindeki I. Mahmut Çeşmesi, Kültür Bakanlığı Yayınları, Ankara 
taşlarında, çeşitli anıtlarda, tahta işçilikte, cam işçilikte, halı-kilim-seccadelerde, kumaşlarda, el işlerinde hayat ağacının ve ölümsüzlüğün simgesi servili örnekler bulunmaktadır ${ }^{11}$. Serviler özellikle ç̧şmelerde de çok yoğun olarak ele alınmıştır. Kabataş Hekimoğlu Ali Paşa Meydan Çeşmesinin yola ve denize bakan cephelerindeki ayna taşında uçları sağa ve sola kıvrık karşılıklı birer servi ${ }^{12}$, Ortaköy Damat İbrahim Paşa Çeşmesinin ayna taşında ${ }^{13}$, Topkapı Sarayındaki 239 envanter numaralı lale motifiyle bezenmiş ayna taşının iki yanında ${ }^{14}$, Ayvansaray'daki Kasapbaşı Hasan Efendi Çeşmesi, Topçubaşı İsmail Ağa Çeşmesi ${ }^{15}$, Beyoğlu Kaptan Hacı Hüseyin Paşa Çeşmesi $^{16}$, Topçubaşı İsmail Ağa Çeşmesinde ${ }^{17}$ uçları karşıllıklı olarak birbirine bakan, içleri taralı servi ağaçları nakş olunmuştur. Gördes Ağalar Mezarlığı'nda ${ }^{18}$, Büyük Mezarlıkta ${ }^{19}$, Hüseyni Baba Mezarlığı'nda ${ }^{20}$ benzer tasvirler göze çarpmaktadır.

Gördes mezarlıklarında bazı baş taşlarının arkasında ve ayak taşlarında yer alan serviler tek olarak tasvir edilmiştir. Ancak servilerin uçları bazıları sağa, çok azı da dikey vaziyette taşlarda işlenmiştir. Serviler şekil itibarıyla düz ve sade olabildikleri gibi, genelde iki yanında horoz ibiği çiçeği, kıvrık dal ve yıldız-hilal motifleriyle beraber mezarlıklarda servi motifi tasvir edilmiştir. Bunlar baş taşlarının üçgen alınlığında mimari kompozisyon içinde, ayak taşlarında veya başlıklarda işlenmiştir ${ }^{21}$.

Osmanlı Döneminde akantus motifi batılılaşmayla birlikte gerek mimari plastikte, gerek duvar resimlerinde ve gerekse de mezar taşlarında, barok ve rokoko döneminin antinatüralist yani stilize edilmiş ve bunun yanında türlü biçimlere girmiş olarak yer aldığı göze çarpmaktadır. Alaşehir Kesik

1992; H. Örcün Barışta, Kabataş Hekimoğlu Ali Paşa Meydan Çeşmesi, Kültür Bakanlığı Yayınlar1, Ankara

1993; H. Örcün Barışta, İstanbul Azapkapı Saliha Sultan Çeşmesi, Kültür Bakanlığı Yayınları, Ankara 1995.

11 Bkz. Cevdet Çulpan, Antik Devirlerden Zamanımıza Kadar İlahiyat-Edebiyat-Tıp ve Sanat Tarihlerinde Serviler, II, İstanbul 1961, s.101-138.

12 Barışta, 1993, a.g.e., 32.

13 Barışta, 1992, a.g.e.,12.

14 Barışta, 1992, a.g.e., 65.

15 Barışta, 1992, a.g.e., 74, 76

16 Barışta, 1991, a.g.e.,12-13.

7 Barıșta, 1991, a.g.e., 37.

18 Biçici, 2004, a.g.t., 49-51, 54-55, 56-57, 85-86.

19 Biçici, 2004, a.g.t., 286-288, 291-292, 360-361, 384-386, 441-442, 483-484, 501-502, 541 542, 577-578, 579- 580.

20 Biçici, 2004, a.g.t., 680-682, 690-691.

${ }^{21}$ Biçici, 2004, a.g.t.,772-774,779. 
Minare Camisi, Akhisar Ulu Camisi, Manisa Nişancıpaşa Camisi (Fatıma bin Resuli Mutlak'ın), Menemen Mahkeme Camisi Hazirelerinde bir saksıdan demet şeklinde çıkan akantuslar göze çarpmaktadır ${ }^{22}$. Bunlar üste ve yanlara doğru kıvrılmaktadır. Akantusların oluşturduğu benzer bezemeler Gördes'te yukarıda sayılan mezar taşlarında da görülmektedir ${ }^{23}$. Gördes mezar taşlarında stilize edilmiş akantus yaprakları kitabenin üstünde, üçgen alınlıkta ve ayaktaşlarında bulunmaktadır. Akantusla birlikte ayçiçeği motifinin yer aldığı Osmanlı dönemi benzer mezar taşı örnekleri Büyük Mezarlıkta göze çarpmakta ve üç örnekte yer almaktadır ${ }^{24}$.

Rozet çiçeği motifi İzmir Pınarbaşı mezarlıklarında yer alan müezzin Sabri Efendi'nin kızı Hüsniye Hanımın 1912 tarihli şahide de ve aynı yerde yazısız lahitli mezar taşında rozet çiçeği dikkat çekmektedir ${ }^{25}$.

Osmanlı dönemi Gördes mezar taşlarında rozet çiçeği baş taşının tepeliğinde, başlıkta, vazoda, tepeliği dilimli olan taşların ortasında yer alan madalyona benzer dairenin içinde ve alt iki yan diliminde, kitabenin üst iki yan köşesinde ve ayak taşında stilize edilmiş bir biçimde işlenmiştir ${ }^{26}$.

Yıldız ve hilal motifi baş taşının tepeliğinde ve ayak taşlarında hilal motifiyle bir arada ele alınmıştır. Gördes'te ${ }^{27}$, Kuzeybatı Anadolu Bölgesindeki mezarlıklarda ve hazirelerde yer alan mimari bezemeli mezar taşlarında, hilal motifi kompozisyon içinde sıkça karşımıza çıkmaktadır ${ }^{28}$.

Geometrik bezemelerden olan yelpaze, damla, istiridye veya yarım rozet çiçeğini hatırlatan motif, bir merkezden çıkan ve etrafa dağılan, daha çok damla motifi şeklinde işlenmiş ışın çubukları gibi görünümdedir. Işın çubuğu motifi, tepeliği üç dilimli olan mezar taşları arasında daha çok karşılaşılmaktadır. Osmanlı dönemine ait, bu motifle bezemeli şahideler mezarlıkların en eski örnekleri arasındadır ${ }^{29}$, Baş taşının tepeliğ̈inde ve ayak taşında çoğunlukla diğer bitkisel unsurlarla beraber yer alan örnekler XIX.yy.sonu ve XX.yy. başına tarihlenen örneklerdir . İncelediğimiz ışın çubuk motifli örnekler ise 1933 ile 1941 yılları arasındadır. Işınsal çubuklar Gördes dışın-

Biçici, 2004, a.g.t., 769

Biçici, 2004, a.g.t., 57, 394, 410, 412, 424, 476, 478, 769.

Biçici, 2004, a.g.t., 429-430, 700-701.

25 Bkz. Necmi Ülker, "İzmir'in Pınarbaşı Mezar Kitabeleri I (XVIII-XIX.yüzyıl)", II. Araştırma Sonuçları Toplantısı, 16-20 Nisan 1984, Ankara, 1985, s.12,13.

26 Biçici, 2004, a.g.t., 778.

27 Biçici, 2005, a.g.t., 786, 788.

28 Bkz. Gül Tunçel, Batı Anadolu Bölgesinde Cami Tasvirli Mezartaşları, Kültür Bakanlığı Yayınlar1, Ankara 1989, s. 17, 21, 23, 27,37, 41, 57,63, 66, 68, 70, 78, 80, 84, 88, 90, 94, 100, 111, $120,125,137,141,146,155,156,173,179,192,200,208,211,212)$

29 Biçici, 2004, a.g.t., 786-787. 
da Amasya mezar taşlarında üç örnekte görülmektedir, çubukların ucu V şeklinde çatallıdır ${ }^{30}$, bu motif Antalya Müzesinde ${ }^{31}$, çeşmelerde ${ }^{32}$ ele alındığı gözlenmektedir. Gerek Amasya, gerek Antalya, gerekse İstanbul'un çeşitli semtlerinde yer alan çeşmelerde istiridye veya yelpaze görünümlü ışın çubukları Gördes'te bulunan örneklere benzemekte, bunun İstanbul ve Anadolu'da özellikle mimari yapılar ile mezar taşlarında dönemin modası olarak devam ettiği, XVIII.yy.da yoğun olarak kullanıldığı, sonra kullanımının terk edildiği anlaşılmaktadır. Bu motifin birçok yerde benzerine rastlanılan misallerinden birisi de Tire Müzesinde ${ }^{33}$ görülmektedir.

Bir süs eşyası olan takılar, Osmanlı döneminde mezar taşlarında da beğenilerek kullanılmıştır. Takı motifleri Gördes'te Osmanlının son döneminden başlayarak günümüze değin kadın mezar taşlarında ele alınmıştır ${ }^{34}$. Akşehir müzesinde boynunda gerdanlık bulunan bir sfenksle başlayan örnekler ${ }^{35}$ XVI.yy.dan XX.yy.a kadar olan zaman dilimi içerisinde mezar taşlarında yer almıştır. Manisa Nişancıpaşa Cami haziresinde yer alan Hacı Cemal kızı Hadice Fahriye Hanım'ın 1911 tarihli ve Muhammed Efendi kızı İhsan Züleyha'nın 1895 tarihli mezar taşlarında boyun kısmının iki yanından sallanan gerdanlık konu edilmiştir ${ }^{36}$.

Vazo motifi duvar çinilerinde, seramiklerde, taş mermer üzerinde (özellikle çeşmelerde ve mezar taşlarında), eski resim ve minyatürlerde, tezhiplerde, tahta üzerindeki nakışlarda, sedef işlerinde, kağıt oymacılığında, işlemelerde beğenilen bir motif olarak çok kullanılmıştır ${ }^{37}$. Tasvirler şahidenin tepeliğinde veya alınlığında veya tepeliğinde vazo içerisinde akantus yaprakları, çiçeklerle, birlikte ele alınmıştır. Gördes mezarlıklarında ${ }^{38}$, Tire Yeni Cami haziresinde bulunan Hacı Aişe Hanım'ın 1841 tarihli şahidesinin tepeliğinde kaideli bir vazodan çıkan, Manisa Müzesi'nde bulunan Hayatım Ka-

30 Günnur Aydoğdu, Amasya Mezar Taşları, Gazi Üniversitesi Sosyal Bilimler Enstitüsü Sanat Tarihi Anabilim Dalı (Basılmamış Yüksek Lisans Tezi), Ankara 1997, s. 262

31 Naci Eren, "Antalya Müzesinde Bulunan Eski Türk Mezar Taşları", TED, sayı: XVII, Ankara 1982, s. 115-134, res. 34.

32 Barışta 1991, a.g.e.; Barışta 1992, a.g.e.

33 Necmi Ülker, "Tire Müzesindeki İslami Kitabeler", III. Araştırma Sonuçları Toplantısı, 20-24 Mayıs 1985, Ankara, Kültür Bakanlığı Yayınları, Ankara 1986, s. 15-16.

34 Biçici, 2004, a.g.t., 791-792.

35 H. Örcün Barışta, "Osmanlı İmparatorluğu Dönemi Türk Mezar Taşlarından Bazı Takı Tasvirleri”, XIII.Türk Tarih Kongresi, Ankara 4-8 Ekim 1999, Kongreye Sunulan Bildiriler, III. c. II. kısım, Ankara 2002, s. 1309-1313, Fot. 1-18, Çiz. 1-27.

36 Biçici, 2004, a.g.t., 792.

37 Azade Akar, "Tezyini Sanatlarımızda Vazo Motifleri”, Vakıflar Dergisi, Sayı: VIII, Ankara 1969, s. 267-272.

38 Biçici, 2004, a.g.t., 792-793. 
dın'ın 1798 tarihli şahidesinde ${ }^{39}$, İzmir Şeyh Cami Haziresi'nde yer alan Şerife Aişe'nin 1808 tarihli mezar taşında ${ }^{40}$ vazo motifleri incelediğimiz örneklere benzer şekilde işlenmiştir.

Bu örnekler içerisinde bir örnekte yalnızca alem veya alemle birlikte cami kubbesinin küçük bir kısmı verilerek cami simgelenmek istenmiştir. Buna benzer kompozisyonlar daha çok dilimli tepeliği olan, 1şın çubuğu bezemeli Osmanlı dönemi mezar taşlarında gözlenmektedir ${ }^{41}$. Şahidelerin büyük bir kısmının ele alınışında temiz işçilikle beraber, seçilen motiflerin kompozisyonda birbirleriyle ahenkli verilişi dikkat çekmektedir. Bunun yanında da bir kısım şahidelerin işlenişinde oldukça sadelik, çizgisellik hakimdir.

Sonuç olarak Cumhuriyet döneminden yakın tarihe kadar geleneksel üslupta yapılmış olan, Osmanlı mezarlarıyla neredeyse iç içe duran ve sayıları da fazla olmayan incelediğimiz 14 mezar taşı, konu bakımından bitkisel (akantus, ayçiçeği, gül, horoz ibiği, kıvrık dal, küpe, lale, rozet, servi, yaprak), geometrik (hilal, ışın çubuğu, yıldız, zincir) ve nesneli bezemelidir. (alem, takı, vazo). Bir kısmının da (No.3, 13, 14) bazı Osmanlı şahideleri gibi taşın yüzeyinin veya bezemelerinin boyanarak verildiği (fot.4, 5, 7, 22) göze çarpmaktadır. Az bir mezar taşıyla sonuca varmak şüphesiz zordur. Fakat bununla birlikte, süsleme konuları açısından, bezemelerin taşın yüzeyine yani bilhassa tepelik, alınlık ve ayak taşlarının gövdesine yerleştiriliş biçiminden, Latin alfabeli olarak kitabelerde geçen dua, şiir, yakarış sözlerinin anlam benzerliği yönünden, Osmanlı dönemi mezar taşlarının bir deva$\mathrm{m} ı$ niteliğinde olduğu akla gelmektedir. İlk defa bir taşçı ustasının isminin geçmesi, kitabelerin bir kısmında doğum ve ölüm tarihlerinin bir arada verilmesi, süslemelerde yer yer göze çarpan sadelikle birlikte, bezemelerde deformasyona rastlanılması gibi özellikleriyle Osmanlı dönemi mezar taşlarından ayrılmaktadır. Osmanlı sonrasının ilk dönemlerinde kullanılan mermer malzeme, daha sonrada kullanılmaya devam etmiş ama özellikle mimari kompozisyonlu mezar taşlarının bazılarında dökme beton ve alçı karışımı bir malzeme kullanıldığı anlaşılmıştır. ${ }^{42}$ Mermer malzemenin zaman içinde kalınlığının azalmasının ve mermer cinsinin değişmesinin yanında, ölçü bakımından da Osmanlı döneminde yapılanlardan daha kısa boyutlu yapıldıkları müşahade edilmiştir. Bütün bunlarda bize geçmişin izlerinin, beğenilerin devam ettiğini, zaman içinde ekonomik şartlarında mezar taşlarının ele alınış biçiminde önemli bir faktör olduğunu göstermektedir.

39 Tunçel, 1989, a.g.e., 31-33.

40 Tunçel, 1989, a.g.e., 31-33; 47-49.

41 Biçici, 2004, a.g.t., 794.

42 Biçici, 2005, a.g.m., 1-15. 